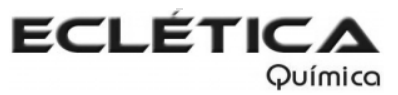

www.scielo.br/eq

Volume 31, número 1, 2006

\title{
Synthesis, characterization and thermal behaviour of solid- state compounds of 4-methoxybenzoate with lanthanum (III) and trivalent lighter lanthanides
}

\author{
E. C. Rodrigues ${ }^{1}$, A. B. Siqueira ${ }^{1}$, E. Y. Ionashiro ${ }^{I}$, G. Bannach Band M. Ionashiro $^{I}$ \\ 'Instituto de Química, UNESP, C. P. 355, CEP 14801 - 970 Araraquara, SP, Brazil
}

\begin{abstract}
Solid-state M-4-MeO-Bz compounds, where $\mathrm{M}$ stands for trivalent $\mathrm{La}, \mathrm{Ce}, \mathrm{Pr}, \mathrm{Nd}$ and $\mathrm{Sm}$ and 4-MeO-Bz is 4-methoxybenzoate, have been synthesized. Simultaneous thermogravimetry and differential thermal analysis (TG-DTA), differential scanning calorimetry (DSC), X-ray powder diffractometry, infrared spectroscopy and complexometry were used to characterize and to study the thermal behaviour of these compounds. The results led to information about the composition, dehydration, polymorphic transformation, ligand's denticity, thermal behaviour and thermal decomposition of the isolated compounds.
\end{abstract}

Keywords: lighter lanthanides; 4-methoxybenzoate; characterization; thermal behaviour.

\section{Introduction}

Benzoic acid and some of its derivatives are used as conservant, catalyst precursors of polymers, in pharmaceutical industries, beyond other applications. A survey of literature shows that the complexes of rare earth and d-block elements with benzoic acids and some of its derivatives have been investigated in aqueous solutions and in the solid state.

In aqueous solutions, the papers reported the thermodynamics of complexation of lanthanides by some benzoic acid derivatives [1], the spectroscopic study of trivalent lanthanides with several carboxylic acids including benzoic acid [2], the influence of $\mathrm{pH}$, surfactant and synergic agent on the luminescent properties of terbium chelates with benzoic acid derivatives [3], the thermodynamic of complexation of lanthanides by benzoic and isophthalic acids [4] and the synthesis, crystal structure and photophysical and magnetic properties of dimeric and polymeric lanthanide complexes with benzoic acid and its derivatives [5].
In the solid state the papers reported the thermal stability and thermal decomposition of thorium salts with several organic acids, including 4-methoxybenzoic acid [6], as well as benzoic and m-hydroxybenzoic acids [7]; the thermal decomposition of nickel benzoate and of the nickel salt of ciclohexane carboxylic acid [8]; the thermal and spectral behaviour on solid compounds of benzoates and its methoxy derivates with rare earth elements [9-16]; the vibrational and electronic spectroscopic study of lanthanides and effect of sodium on the aromatic system of benzoic acid $[17,18]$; the reaction of bivalent cooper, cobalt and nickel with 3-hidroxy-4-methoxy and 3-methoxy4-hidroxybenzoic acids and a structure for these compounds has been proposed on the basis of spectroscopic and thermogravimetric data [19]; the thermal decomposition of thorium salts of benzoic and 4-methoxybenzoic acids in air atmosphere [20]; the thermal and spectral behaviour on solid compounds of 5-chloro-2-methoxybenzoate with rare earth and d-block elements [21-24]; the synthesis and characterization of 2,3-dimethoxyben- 
zoates of heavy lanthanides and yttrium [25]; the thermal studies on solid compounds of phenyl substituted derivates of benzyllidenepyruvates with several metal ions [26, 27]; the spectral and magnetic studies of 2-chloro-5-nitrobenzoates of rare earth elements [28] and thermal behaviour of solid state 4-methoxybenzoates of some bivalent transition metal ions [29].

In this work 4-methoxybenzoates of $\mathrm{La}(\mathrm{III}), \mathrm{Ce}(\mathrm{III}), \mathrm{Pr}(\mathrm{III}), \mathrm{Nd}$ (III) and Sm(III) were synthetized. The compounds were investigated by means of infrared spectroscopy, X-ray powder diffractometry, simultaneous thermogravimetry and differential thermal analysis (TG-DTA), differential scanning calorimetry (DSC) and other methods of analysis.

\section{Experimental}

The 4-methoxybenzoic acid (4-MeO-HBz) 98\% was obtained from Acros Organics and purified by recrystallization. Aqueous solution of $\mathrm{Na}-$ 4-MeO-Bz $0.1 \mathrm{~mol} \mathrm{~L}^{-1}$ was prepared from aqueous 4-MeO-HBz suspension by treatment with sodium hydroxide solution $0.1 \mathrm{~mol} \mathrm{~L}^{-1}$. Lanthanum and lanthanide chlorides were prepared from the corresponding metal oxides (except for cerium) by treatment with concentrated hydrochloric acid. The resulting solutions were evaporated to near dryness, the residues were again dissolved in distilled water, transferred to a volumetric flask and diluted in order to obtain ca. $0.1 \mathrm{~mol} \mathrm{~L}^{-1}$ solutions, whose $\mathrm{pH}$ were adjusted to 5.5 by adding diluted sodium hydroxide or hydrochloric acid solutions. Cerium (III) was used as its nitrate and ca. $0.1 \mathrm{~mol}$ $\mathrm{L}^{-1}$ aqueous solutions of this ion were prepared by direct weighing of the salt. The solid state compounds were prepared by adding slowly, with continuous stirring, the solution of the ligand to the respective metal chloride or nitrate solutions, until total precipitation of the metal ions. The precipitates were washed with distilled water until elimination of the chloride (or nitrate) ions, filtered through and dried on Whatman $\mathrm{n}^{\circ} 42$ filter paper, and kept in a desiccator over anhydrous calcium chloride, under reduced pressure to constant mass.

In the solid state compounds, hydration water, ligand and metal ion contents were deter- mined from TG curves. The metal ions were also determined by complexometric titrations with standard EDTA solution, using xylenol orange as indicator [30, 31].

$\mathrm{X}$-ray powder patterns were obtained by using a Siemens D-5000 X-ray diffractometer, employing $\mathrm{Cu} \mathrm{K \alpha}$ radiation $(\lambda=1.541 \AA)$ and settings of $40 \mathrm{kV}$ and $20 \mathrm{~mA}$.

Infrared spectra for $\mathrm{Na}-4-\mathrm{MeO}-\mathrm{Bz}$ as well as for its metal-ion compounds were run on a Nicolet model Impact 400 FT-IR instrument, within the $4000-400 \mathrm{~cm}^{-1}$ range. The solid samples were pressed into $\mathrm{KBr}$ pellets.

Simultaneous TG-DTA curves were obtained with thermal analysis system model SDT 2960 from TA Instruments. The purge gas was an air flow of $100 \mathrm{~mL} \mathrm{~min}^{-1}$. A heating rate of $20{ }^{\circ} \mathrm{C} \mathrm{min}{ }^{-1}$ was adopted with samples weighing about $7 \mathrm{mg}$. Platinum crucibles were used for recording the TG-DTA curves.

DSC curves were obtained with thermal analysis systems model DSC 25 from Mettler Toledo. The purge gas was an air flow of $100 \mathrm{~mL}$ $\mathrm{min}^{-1}$. A heating rate of $20^{\circ} \mathrm{C} \mathrm{m^{-1 }}$ was adopted with samples weighing about $5 \mathrm{mg}$. Aluminium crucibles, with perforated cover, were used for recording the DSC curves.

Computational strategy. Calculation of the theoretical infrared spectrum of lanthanum 4methoxybenzoate is necessary to evaluate the structure and wave function computed by the $a b$ initio SCF Hartree-Fock-Roothan method [32] using a split valence (lanL2DZ) basis set [33-36]. The performed molecular calculations in this work were done by using the Gaussian 98 routine [37] and the hardware used was IBM power 3. The geometry optimization was carried out without any constraints. The molecule of 4-methoxybenzoate contain rings with conformational flexibility, all variables were optimized. The optimization proceeded make uniformly when all variables were optimized.

\section{Results and discussion}

The analytical and thermoanalytical (TG) data are shown in Table 1. These results establish the stoichiometry of these compounds, which are 
Table 1. Analytical and thermoanalytical (TG) data of the compounds.

\begin{tabular}{lccccccccc}
\hline & \multicolumn{3}{c}{ Metal/\% } & \multicolumn{3}{c}{ Loss/\% } & \multicolumn{2}{c}{ Water\% } & \multirow{2}{*}{ Residue $^{\mathrm{a}}$} \\
\cline { 2 - 7 } Compounds & Calcd. EDTA & TG & Calcd. & TG & Calcd. & TG & \\
\hline $\mathrm{La}(\mathrm{L})_{3} .2 \mathrm{H}_{2} \mathrm{O}$ & 22.11 & 22.28 & 22.04 & 68.34 & 68.30 & 5.74 & 5.85 & $\mathrm{La}_{2} \mathrm{O}_{3}$ \\
$\mathrm{Ce}(\mathrm{L})_{3} .1 .5 \mathrm{H}_{2} \mathrm{O}$ & 22.58 & 22.23 & 22.26 & 67.91 & 68.26 & 4.36 & 4.40 & $\mathrm{CeO}_{2}$ \\
$\mathrm{Pr}(\mathrm{L})_{3} .2 \mathrm{H}_{2} \mathrm{O}$ & 22.35 & 22.44 & 22.37 & 67.28 & 67.32 & 5.72 & 5.66 & $\mathrm{Pr}_{6} \mathrm{O}_{11}$ \\
$\mathrm{Nd}(\mathrm{L})_{3} .2 .5 \mathrm{H}_{2} \mathrm{O}$ & 22.44 & 22.25 & 22.65 & 66.82 & 66.98 & 7.04 & 6.60 & $\mathrm{Nd}_{2} \mathrm{O}_{3}$ \\
$\mathrm{Sm}(\mathrm{L})_{3}$ & 24.90 & 25.01 & 25.34 & 71.12 & 70.62 & - & - & $\mathrm{Sm}_{2} \mathrm{O}_{3}$ \\
\hline
\end{tabular}

L means 4-methoxybenzoate

a all residues were confirmed by X-ray powder diffractometry

in agreement with the general formula $\mathrm{ML}_{3} \cdot \mathrm{nH}_{2} \mathrm{O}$, where $M$ represents trivalent $\mathrm{La}, \mathrm{Ce}$, $\mathrm{Pr}, \mathrm{Nd}$ or $\mathrm{Sm}, L$ is 4-methoxybenzoate and $\mathrm{n}=2$; $1.5 ; 2 ; 2.5$ and 0 , respectively.

The X-ray diffraction powder patterns (Fig. 1) show that all the compounds have a crystalline structure and only the La and Pr show evidence for formation of isomorphous compounds.

Infrared spectroscopic data on 4-methoxybenzoate and its compounds with trivalent metal ions considered in this work are shown in Table 2. The investigation was focused mainly within the $1700-1400 \mathrm{~cm}^{-1}$ range because this region is potentially most informative to assign coordination sites. In the sodium 4-methoxybenzoate, strong bands located at $1543 \mathrm{~cm}^{-1}$ and $1416 \mathrm{~cm}^{-1}$ are attributed to the anti-symmetrical and symmetrical frequencies of the carboxylate groups, respectively $[38,39]$. In the compounds considered in this work analysis of the frequencies of the $v_{\text {as }}$ and $v_{\text {sym }}\left(\mathrm{COO}^{-}\right)$bands shows that the lanthanides are linked to the carboxylic group by a bidentate bond with an incomplete equalization of bond lengths in the carboxylate anion; this is in agreement with the literature [40].

The theoretical infrared spectrum of anhydrous lanthanum compound was calculated by using a harmonic field [41] and the obtained frequencies were not scaled. The geometry optimization was computed by the optimized algorithm of Berny [42].

Table 2. Spectroscopic data for sodium 4-methoxybenzoate and compounds with some trivalent íons. ${ }^{\text {a }}$

\begin{tabular}{lcccc}
\hline Compound & $v_{\mathrm{OH}}\left(\mathrm{H}_{2} \mathrm{O}\right)$ & $\begin{array}{c}\mathrm{v}_{\mathrm{as}}\left(\mathrm{COO}^{-}\right)^{\mathrm{b}} \\
\left(\mathrm{cm}^{-1}\right)\end{array}$ & $\begin{array}{c}v_{\text {sym }}\left(\mathrm{COO}^{-}\right)^{\mathrm{b}} \\
\left(\mathrm{cm}^{-1}\right)\end{array}$ & $\Delta v^{\mathrm{c}}$ \\
\hline $\mathrm{NaL}$ & - & $1543_{\mathrm{s}}$ & $1416_{\mathrm{s}}$ & 127 \\
$\mathrm{La}(\mathrm{L})_{3} \cdot 2 \mathrm{H}_{2} \mathrm{O}$ & $3470_{\mathrm{br}}$ & $1524_{\mathrm{s}}$ & $1421_{\mathrm{s}}$ & 103 \\
$\mathrm{Ce}(\mathrm{L})_{3} \cdot 1.5 \mathrm{H}_{2} \mathrm{O}$ & $3443_{\mathrm{br}}$ & $1522_{\mathrm{s}}$ & $1416_{\mathrm{s}}$ & 106 \\
$\mathrm{Pr}(\mathrm{L})_{3} \cdot 2 \mathrm{H}_{2} \mathrm{O}$ & $3431_{\mathrm{br}}$ & $1522_{\mathrm{s}}$ & $1418_{\mathrm{s}}$ & 104 \\
$\mathrm{Nd}(\mathrm{L})_{3} \cdot 2.5 \mathrm{H}_{2} \mathrm{O}$ & $3439_{\mathrm{br}}$ & $1522_{\mathrm{s}}$ & $1416_{\mathrm{s}}$ & 106 \\
$\mathrm{Sm}(\mathrm{L})_{3}$ & - & $1508_{\mathrm{s}}$ & $1387_{\mathrm{s}}$ & 121 \\
\hline br - broad; s - strong; $\mathrm{L}=4-$ methoxybenzoate; & $v_{\mathrm{OH}}=$ hydroxyl group stretching frequency; \\
$v_{\text {sym }}$ and $v_{\text {asym }} \mathrm{COO}^{-}=$symmetrical and anti-symmetrical vibrations of the COO - structure.
\end{tabular}




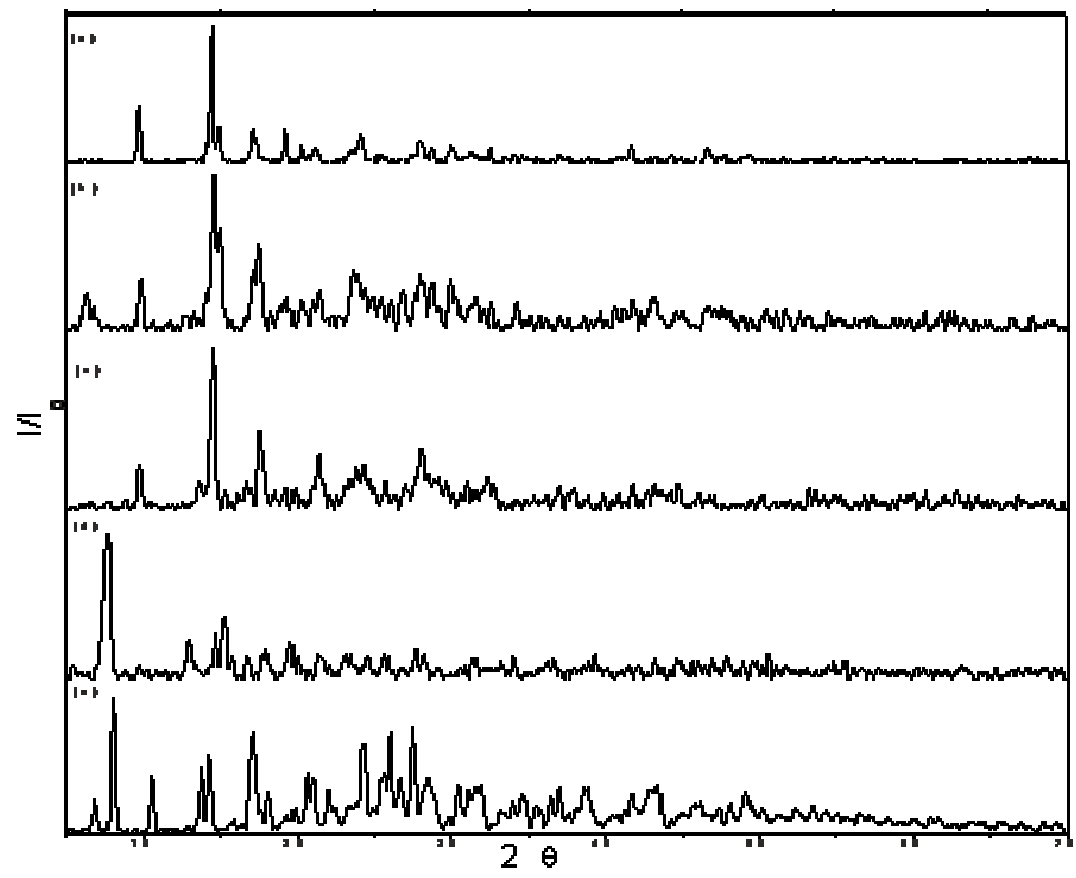

Figure 1. X-ray powder diffraction patterns of the compounds (a) $\mathrm{La}(\mathrm{L})_{3} \cdot 2 \mathrm{H}_{2} \mathrm{O}$; (b) $\mathrm{Ce}(\mathrm{L})_{3} \cdot 1.5 \mathrm{H}_{2} \mathrm{O}$; (c) $\operatorname{Pr}(\mathrm{L})_{3} \cdot 2 \mathrm{H}_{2} \mathrm{O}(\mathrm{d}) \mathrm{Nd}(\mathrm{L})_{3} \cdot 2 \cdot 5 \mathrm{H}_{2} \mathrm{O}(\mathrm{e}) \mathrm{Sm}(\mathrm{L})_{3} ; \quad(\mathrm{L}=4$-methoxybenzoate).

The obtained geometry from calculations is presented in Figure 2 and Table 3. The theoretical infrared spectrum (electronic state ${ }^{1} \mathrm{~A}$ ) was obtained with frequency values $\left(\mathrm{cm}^{-1}\right)$, relative intensities, assignments and description of vibrational modes. A comparative analysis between the experimental and theoretical spectrum shows the following conclusions: (a) the first assignment shows a strong contribution at $1524 \mathrm{~cm}^{-1}$ suggesting a $v_{\text {asym }}\left(\mathrm{COO}^{-}\right)$assignment, while the theoretical results show the corresponding peak at $1550 \mathrm{~cm}^{-1}$ with discrepancies of $1.7 \%$ (b) the second assignment shows a strong contribution at $1421 \mathrm{~cm}^{-1}$ suggesting a $v_{\text {sym }}\left(\mathrm{COO}^{-}\right)$assignment, while the theoretical results show the corresponding peak at $1410 \mathrm{~cm}^{-1}$ with discrepancies of $0.8 \%$ (c) the third assignment shows both experimental and theoretical $? v$ values $\left(v_{\text {asym }}\left(\mathrm{COO}^{-}\right)-v_{\text {sym }}\left(\mathrm{COO}^{-}\right)\right)$are near of the sodium methoxybenzoate ? $v$ value $\left(? v_{\mathrm{Na}}=\right.$ $127 ; ? v_{\text {exp }}=103 ; ? v_{\text {Theor }}=140$ ), reinforcing the suggestion that the compounds considered in this work the metal ions are linked to the carboxylic group by a bidentate bond.
Simultaneous TG-DTA curves of the compounds are shown in Figs 3, 6-9. These curves show mass losses in steps, corresponding to endothermic peaks due to dehydration and crystalline transition or exothermic peaks attributed to oxidation of the organic matter. In all the TG-DTA curves, the mass loss profile shows that the sample temperature is greater than the oven temperature, indicating that the oxidation of the organic matter is accompanied by the combustion. The thermal stability of the anhydrous compounds as well as the thermal behaviour of the compounds is heavily dependent on the nature of the metal ion as shown by the TG-DTA curves, and so the features of each compound are discussed individually.

Lanthanum compound. The simultaneous TG-DTA curves are shown in Fig. 3. These curves show mass losses in steps and thermal events corresponding to these losses or due to the crystalline phase transition. The first mass loss observed between $77-136^{\circ} \mathrm{C}$ (TG), corresponding to an endothermic peak at $120^{\circ} \mathrm{C}$ (DTA) is due to the 


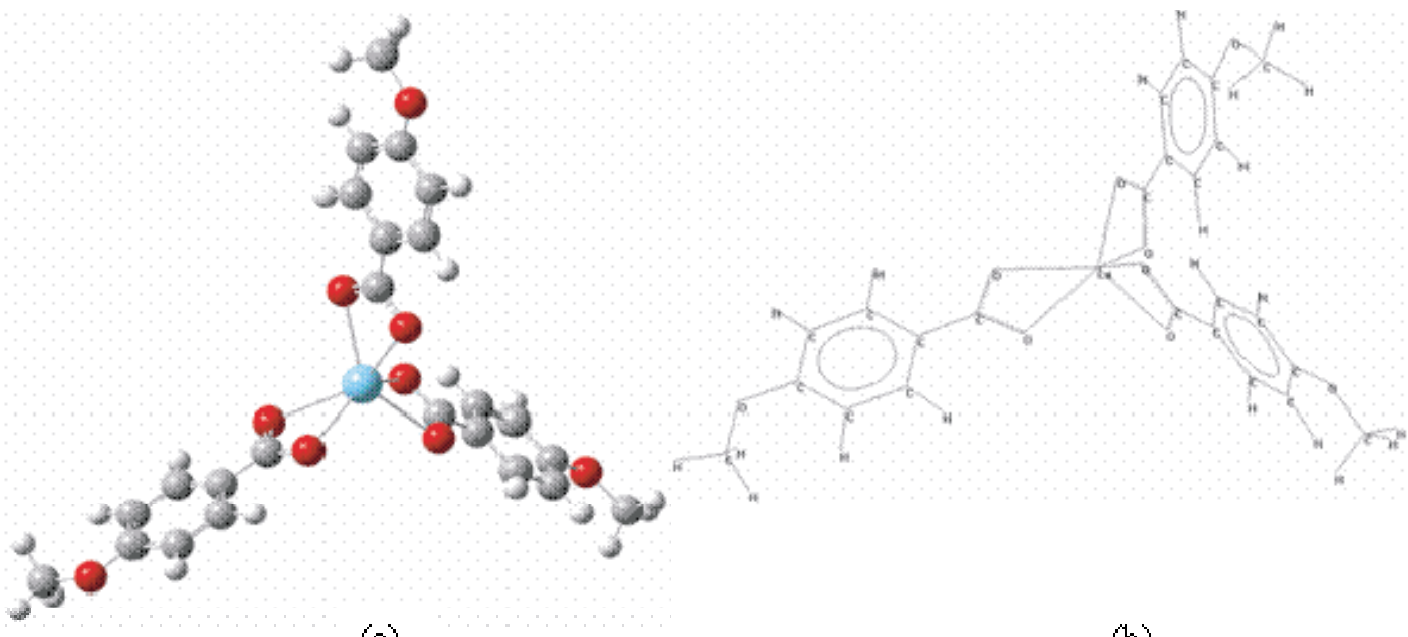

(a)

(b)

Figure 2. Proposed structure 3D (a) and 2D (b) of solid-state anhydrous compound lanthanum (III) with 4-methoxybenzoate (Gaussian 98).

hydration water; it reflects the loss of $2 \mathrm{H}_{2} \mathrm{O}$ (Calcd. $=5.74 \%$; $\mathrm{TG}=5.85 \%)$. The anhydrous compound is stable up to $285^{\circ} \mathrm{C}$, and above this temperature the mass loss occurs in two steps. The first mass loss observed between 285 and $490^{\circ} \mathrm{C}$, corresponding to an exotherm with three peaks at 430,455 and $490^{\circ}$ with loss of $62.89 \%$ is attributed to the oxidation of the organic matter. In this step

Table 3. Theoretical geometries parameters of $\mathrm{La}(\mathrm{L})_{3}$ anhydrous compound.

\begin{tabular}{|c|c|c|c|c|}
\hline d & $\mathrm{La}$ & $-\mathrm{O}_{\mathrm{COO}}^{-}$ & & $2.54 \AA$ \\
\hline d & $\mathrm{C}_{\mathrm{COO}}^{-}-$ & $\mathrm{O}_{\mathrm{COO}}^{-}$ & & $1.29 \AA$ \\
\hline d & $\mathrm{C}_{\mathrm{COO}}^{-}$ & $-\mathrm{C}_{\text {ring }}$ & & $1.46 \AA$ \\
\hline$d$ & $\mathrm{C}_{\mathrm{r}}$ & $\mathrm{C}_{\text {ring }}$ & & $1.39 \AA ̊$ \\
\hline d & $\mathrm{C}_{\text {ring }}$ & $\mathrm{H}_{\text {ring }}$ & & $1.07 \AA$ \\
\hline d & $\mathrm{C}_{\text {ring }}$ & $\mathrm{O}_{\mathrm{MeO}}$ & & $1.37 \AA$ \\
\hline d & $\mathrm{C}_{\mathrm{MeO}}$ & $-\mathrm{O}_{\mathrm{MeO}}$ & & $1.44 \AA$ \\
\hline$d$ & $\mathrm{C}_{\mathrm{MeO}}$ & $-\quad \mathrm{H}_{\mathrm{MeO}}$ & & $1.08 \AA$ \\
\hline d & $\mathrm{C}_{\mathrm{MeO}}$ & $-\quad \mathrm{C}_{\mathrm{MeO}}$ & & $16.32 \AA$ \\
\hline$<$ & $\mathrm{O}_{\mathrm{COO}}^{-}$ & $-\mathrm{C}_{\mathrm{COO}}^{-}$ & $-\mathrm{O}_{\mathrm{COO}}^{-}$ & $116.63^{\circ}$ \\
\hline$<$ & $\mathrm{O}_{\mathrm{COO}}^{-}$ & $-\mathrm{La}$ & $-\mathrm{O}_{\mathrm{COO}}^{-}$ & $64.34^{\circ}$ \\
\hline$<$ & $\mathrm{C}_{\mathrm{MeO}}$ & $-\mathrm{La}$ & $-\mathrm{C}_{\mathrm{MeO}}$ & $30.56^{\circ}$ \\
\hline$<$ & $\mathrm{C}_{\text {ring }}$ & $-\mathrm{O}_{\mathrm{MeO}}$ & $-\mathrm{C}_{\mathrm{MeO}}$ & $121.88^{\circ}$ \\
\hline$<$ & $\mathrm{C}_{\text {ring }}$ & $-\mathrm{C}_{\text {ring }}$ & $-\mathrm{C}_{\text {ring }}$ & $120.55^{\circ}$ \\
\hline$<$ & $\mathrm{O}_{\mathrm{COO}^{-}}$ & $-\mathrm{C}_{\mathrm{COO}}^{-}$ & $-\mathrm{C}_{\text {ring }}$ & $121.69^{\circ}$ \\
\hline
\end{tabular}

Key: $\mathrm{La}=$ lanthanum; $\mathrm{L}=4-$ methoxybenzoate; $\mathrm{d}=$ atoms distance; $<=$ atoms angle; $\mathrm{COO}^{-}=$ carboxylate; ring = benzene ring; $\mathrm{MeO}=$ methoxy group. 
the TG-DTA profiles show that the oxidation is accompanied by combustion with the formation of carbonaceous residue and intermediate compound derivative of carbonate. Tests with hydrochloric acid solution on samples heated up to $500^{\circ} \mathrm{C}$, confirmed the elimination of $\mathrm{CO}_{2}$ and presence of carbonaceous residue. The last step that occurs between 490 and $720^{\circ} \mathrm{C}$, corresponding to the both small exotherm followed by an endotherm with loss of $5.41 \%$ are attributed to oxidation of the carbonaceous residue and thermal decomposition of the intermediate, leading to the lanthanum oxide, $\mathrm{La}_{2} \mathrm{O}_{3}$. The small endothermic peak at $272^{\circ} \mathrm{C}$, without mass loss in the TG curves, is due to the enantiotropic polymorphic transformation, which was confirmed by X-ray powder diffraction patterns (Fig.4) and TG-DTA curves (Fig.5).

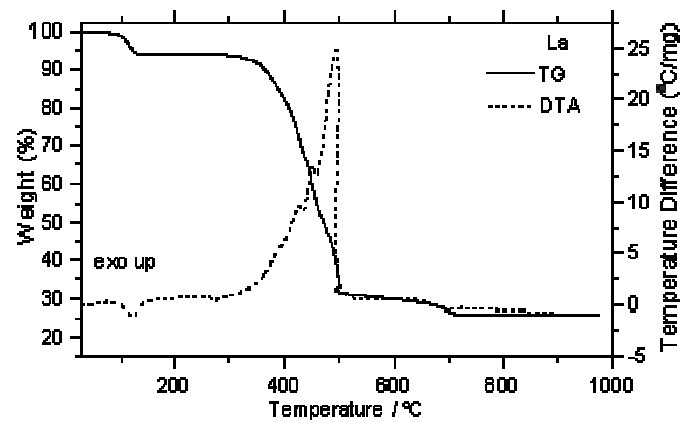

Figure 3. TG-DTA curves of $\mathrm{La}(\mathrm{L})_{3} \cdot 2 \mathrm{H}_{2} \mathrm{O}(\mathrm{L}=4$ methoxybenzoate); $\mathrm{m}=6.8678 \mathrm{mg}$.

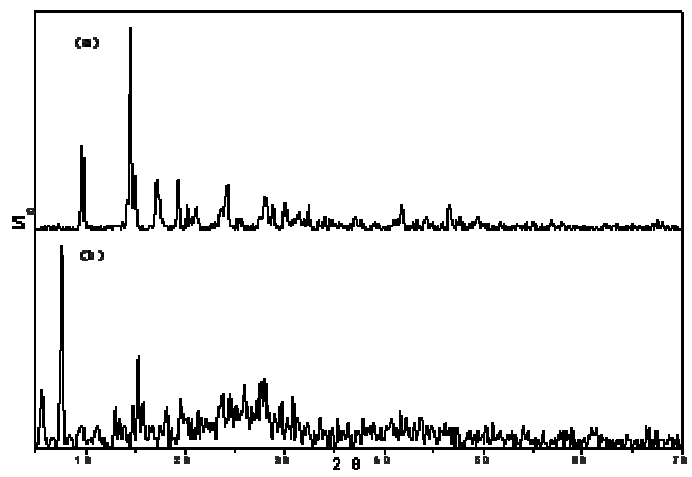

Figure 4. X-ray powder diffraction patterns of the: a) $\mathrm{La}(\mathrm{L})_{3} \cdot 2 \mathrm{H}_{2} \mathrm{O}$; b) $\mathrm{La}(\mathrm{L})_{3} \cdot 2 \mathrm{H}_{2} \mathrm{O}$ heated up to $280^{\circ} \mathrm{C}$.

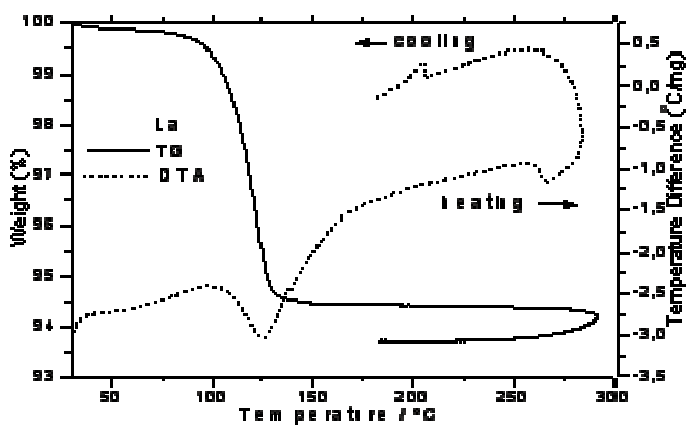

Figure 5. TG-DTA curve of heating and cooling of the compound $\mathrm{La}(\mathrm{L})_{3} \cdot 2 \mathrm{H}_{2} \mathrm{O}$.

Cerium compound. The simultaneous TGDTA curves are shown in Fig. 6. These curves show mass losses in three steps, between 58 and $417^{\circ} \mathrm{C}$. The first mass that occurs up to $122^{\circ} \mathrm{C}$, corresponding to an endothermic peak at $110^{\circ} \mathrm{C}$ is due to the dehydration with loss of $1.5 \mathrm{H}_{2} \mathrm{O}$ (Calcd. = $4.36 \%, \mathrm{TG}=4.40 \%)$. The anhydrous compound is stable up to $260^{\circ} \mathrm{C}$, and above this temperature the thermal decomposition occurs in two overlapping steps between $260-350^{\circ} \mathrm{C}$ and $350-417^{\circ} \mathrm{C}$ with losses of $10.88 \%$ and $57.38 \%$, respectively corresponding to an exothermic peak at $417^{\circ} \mathrm{C}$ attributed to the oxidation reaction of $\mathrm{Ce}(\mathrm{III})$ to $\mathrm{Ce}(\mathrm{IV})$, together with the oxidation of the organic matter. The TG-DTA profiles, also show that the oxidation of the organic matter is accompanied by combustion, and the final residue is the cerium (IV) oxide, $\mathrm{CeO}_{2}$. The small endothermic peaks at $255^{\circ} \mathrm{C}$ and $268^{\circ} \mathrm{C}$ without mass loss in the TG curve are due to the monotropic and enantiotropic polymorphic transformations, respectively.

Praseodymium compound. The simultaneous TG-DTA curves are shown in Fig. 7. These curves show mass losses in three steps, between 54 and $580^{\circ} \mathrm{C}$. The first mass loss observed up to $122^{\circ} \mathrm{C}$, corresponding to an endothermic peak at $106^{\circ} \mathrm{C}$ is due to the dehydration with loss of $2 \mathrm{H}_{2} \mathrm{O}$ (Calcd. $=5.72 \%, \mathrm{TG}=5.66 \%$ ). The anhydrous compound is stable up to $290^{\circ} \mathrm{C}$ and above this temperature the thermal decomposition also occurs in two overlapping steps, between 290$440^{\circ} \mathrm{C}$ and $440-580^{\circ} \mathrm{C}$ with losses of $35.26 \%$ and $32.06 \%$, respectively, corresponding to the exothermic peaks at $424^{\circ} \mathrm{C}$ and $523^{\circ} \mathrm{C}$ attributed to 


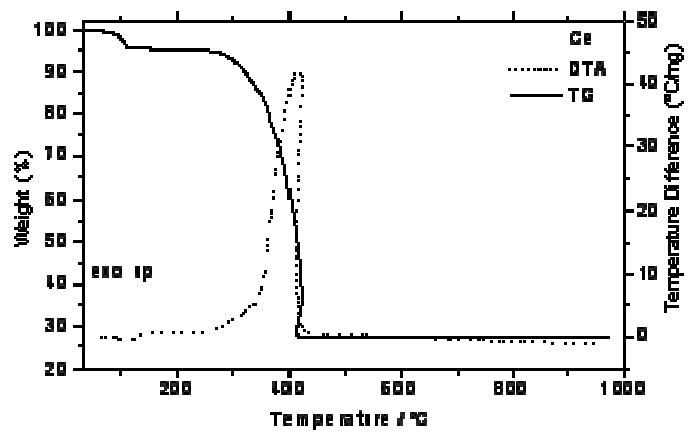

Figure 6. TG-DTA curves of $\mathrm{Ce}(\mathrm{L})_{3} \cdot 1 \cdot 5 \mathrm{H}_{2} \mathrm{O}$ ( $\mathrm{L}=4$-methoxybenzoate); $\mathrm{m}=6.9344 \mathrm{mg}$.

the oxidation reaction of $\operatorname{Pr}(\mathrm{III})$ to $\operatorname{Pr}_{6} \mathrm{O}_{11}$, together with the oxidation of the organic matter. The TG and DTA profiles in the last step also show that the oxidation of the organic matter is accompanied by combustion, with the formation of praseodymium oxide, $\operatorname{Pr}_{6} \mathrm{O}_{11}$. The small endothermic peak at $270^{\circ} \mathrm{C}$ without mass loss in the TG curve is due to the enantiotropic polymorphic transformation.

Neodymium compound. The simultaneous TG-DTA curves are shown in Fig. 8. These curves show mass losses in steps and thermal events corresponding to these losses or due to crystalline phase transition. The first mass loss that occurs between 45 and $120^{\circ} \mathrm{C}$, corresponding to an endothermic peak at $110^{\circ} \mathrm{C}$ is due to hydration water, with loss of $\left.2.5 \mathrm{H}_{2} \mathrm{O}\right)(\mathrm{Calcd} .=7.04 \%$, $\mathrm{TG}$ $=6.60 \%)$. The anhydrous compound is stable up to $305^{\circ} \mathrm{C}$, and above this temperature the thermal

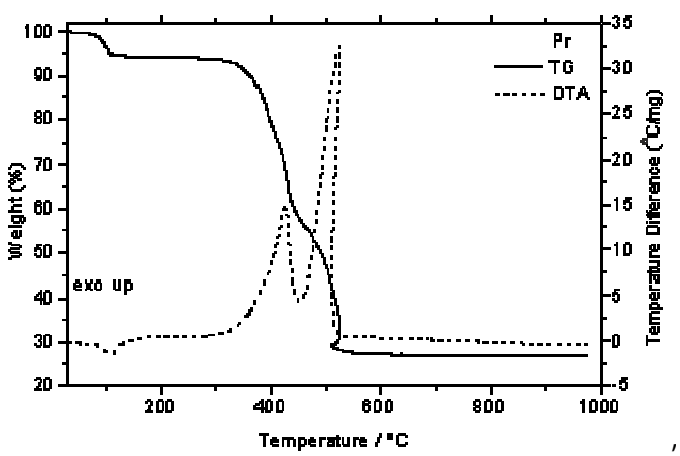

Figure 7. TG-DTA curves of $\operatorname{Pr}(\mathrm{L})_{3} \cdot 2 \mathrm{H}_{2} \mathrm{O}(\mathrm{L}=4$ methoxybenzoate); $\mathrm{m}=7,0770 \mathrm{mg}$.

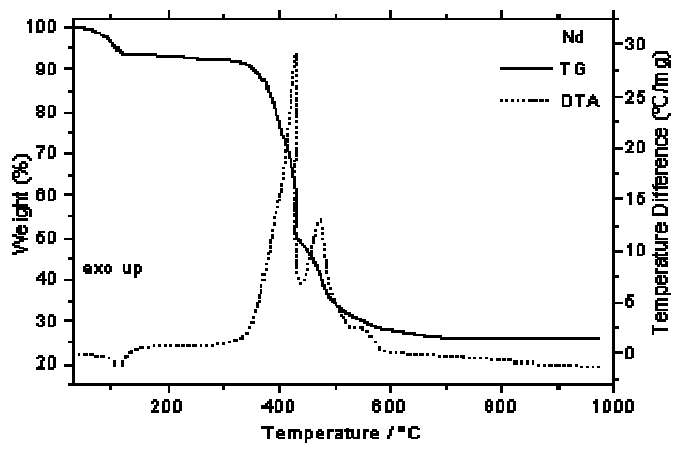

Figure 8. TG-DTA curves of $\mathrm{Nd}(\mathrm{L})_{3} \cdot 2 \cdot 5 \mathrm{H}_{2} \mathrm{O}$ ( $\mathrm{L}=4$-methoxybenzoate); $\mathrm{m}=7.5070 \mathrm{mg}$.

decomposition occurs in four steps. The three first steps that occur through overlapping ones, between $305-429^{\circ} \mathrm{C}, 429-500^{\circ} \mathrm{C}$ and $500-590^{\circ} \mathrm{C}$ with losses of $40.50 \%, 13.50 \%$ and $12.98 \%$, respectively, corresponding to the exothermic peaks at $429^{\circ} \mathrm{C}, 473^{\circ} \mathrm{C}$ and $548^{\circ} \mathrm{C}$, are attributed to oxidation of the organic matter with the formation of an intermediate. Test with hydrochloric acid solution on sample heated up to $590^{\circ} \mathrm{C}$, confirmed the elimination of $\mathrm{CO}_{2}$ and calculations based on the mass loss observed in the TG curve is in agreement with the formation of a mixture of neodymium dioxycarbonate and oxide in no simple stoichiometric relation. The last step observed between 590 and $740^{\circ} \mathrm{C}$, the mass loss occurs through a slow process, attributed to the thermal decomposition of the intermediate to the respective oxide, $\mathrm{Nd}_{2} \mathrm{O}_{3}$. In correspondence with the mass loss, no peak is observed in the DTA curves and this is probably due to the heat involved in this step is insufficient to produce a thermal event. The small endothermic peak at $270^{\circ} \mathrm{C}$ without mass loss in the TG curve is due to the enantiotropic polymorphic transformation.

Samarium compound. The simultaneous TG-DTA curves are shown in Fig. 9. These curves show mass losses in three steps between 299 and $740^{\circ} \mathrm{C}$ and exothermic peaks in correspondence with the two first steps. The two first mass losses that occur through a fast process between 299$415^{\circ} \mathrm{C}$ and $415-490^{\circ} \mathrm{C}$, corresponding to the exothermic peaks at $415^{\circ} \mathrm{C}$ and $490^{\circ} \mathrm{C}$ are attributed to the oxidation of the organic matter. The TG 
and DTA profiles in both steps show that the oxidation of the organic matter is accompanied by combustion, with the formation of a mixture of samarium dioxycarbonate and oxide in no simple stoichiometric relation, as already observed in the neodymium compound. The last mass loss observed between 490 and $740^{\circ} \mathrm{C}$, that occurs through a slow process without thermal event, is ascribed to the thermal decomposition of samarium dioxycarbonate to the respective oxide, $\mathrm{Sm}_{2} \mathrm{O}_{3}$. The small endothermic peaks at $240^{\circ} \mathrm{C}$ and $270^{\circ} \mathrm{C}$ without mass loss in the TG curve are due to the monotropic and enantiotropic polymorphic

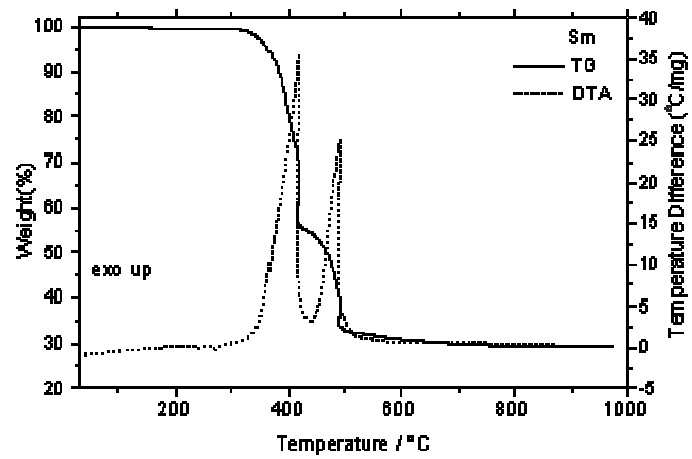

Figure 9. TG-DTA curves of $\mathrm{Sm}(\mathrm{L})_{3}(\mathrm{~L}=4-$ methoxybenzoate); $\mathrm{m}=7.3414 \mathrm{mg}$. transformations respectively, which was confirmed by X-ray powder diffraction patterns (Fig.10), and TG-DTA curves (Fig.11).

For all the compounds the enantiotropic polymorphic transformation is in agreement with the literature data $[13,15,16]$, except the temperatures where all the thermal events occurs; and these differences are undoubtedly because the TG and DTA curves were obtained in conditions enough different. The monotropic polymorphic transformations observed for the cerium and samarium compounds, were not observed in the refs. 13, 15 and 16.

The DSC curves of the compounds are

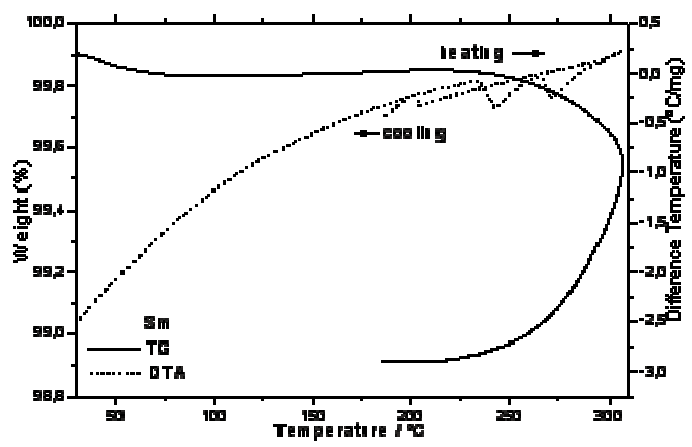

Figure 11. TG-DTA curve of heating and cooling of the compound $\mathrm{Sm}(\mathrm{L})_{3}$.

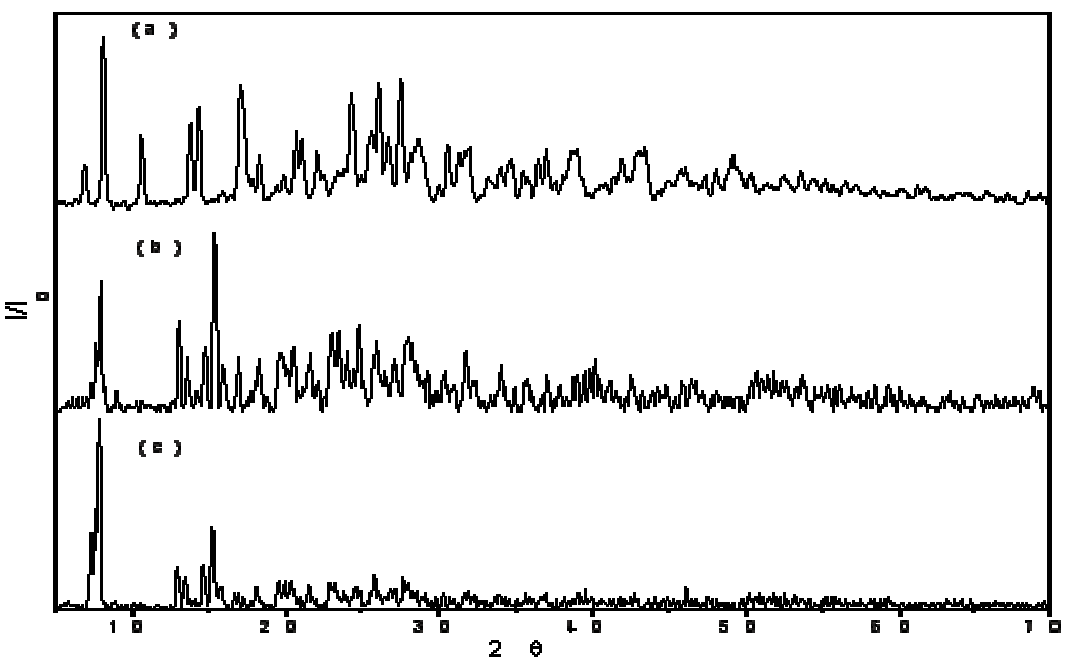

Figure 10. X-ray powder diffraction patterns of the: a) $\mathrm{Sm}(\mathrm{L})_{3}$; b) $\mathrm{Sm}(\mathrm{L})_{3}$ heated up to $260^{\circ} \mathrm{C}$; c) $\mathrm{Sm}(\mathrm{L})_{3}$ heated up to $280^{\circ} \mathrm{C}$. 


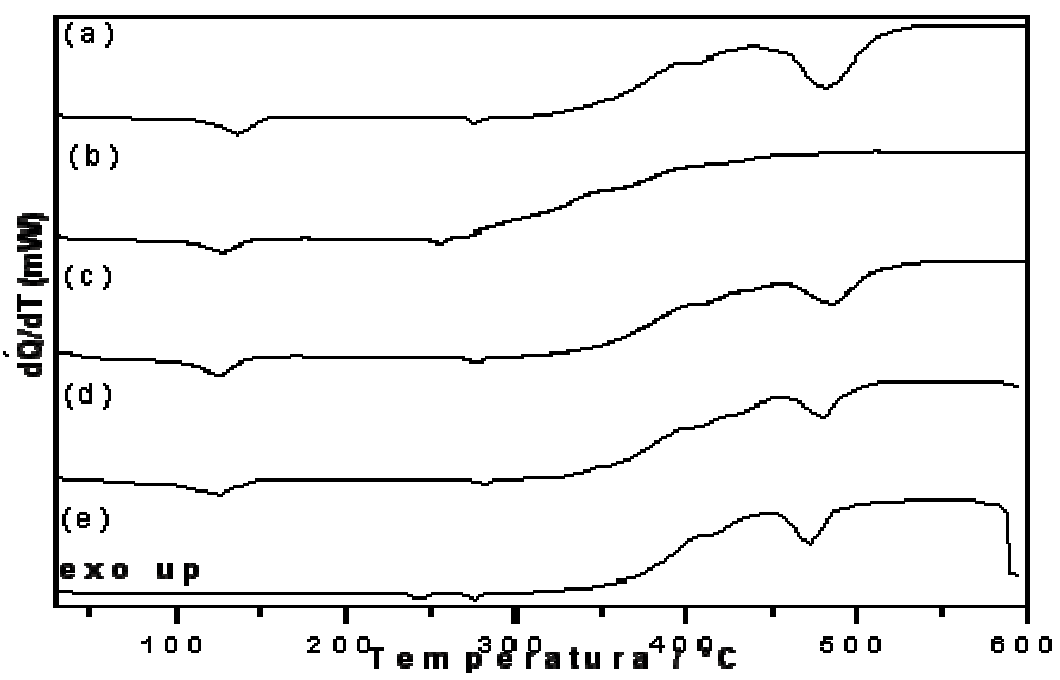

Figure 12. DSC curves of the compounds: a) $\mathrm{La}(\mathrm{L})_{3} \cdot 2 \mathrm{H}_{2} \mathrm{O}(4.8 \mathrm{mg})$; b) $\mathrm{Ce}(\mathrm{L})_{3} \cdot 1.5 \mathrm{H}_{2} \mathrm{O}(5.7 \mathrm{mg})$; c) $\mathrm{Pr}(\mathrm{L})_{3} .2 \mathrm{H}_{2} \mathrm{O}(4.8 \mathrm{mg})$; d) $\mathrm{Nd}(\mathrm{L})_{3} .2 .5 \mathrm{H}_{2} \mathrm{O}(5.0 \mathrm{mg})$ and e) $\mathrm{Sm}(\mathrm{L})_{3}(5.2 \mathrm{mg})$.

shown in Fig.12. These curves show endothermic and exothermic events that all accord with the mass losses observed in the TG curves and endothermic peaks due to crystalline phase transition. The endothermic peak at $130^{\circ} \mathrm{C}(\mathrm{La})$ and $125^{\circ} \mathrm{C}(\mathrm{Ce}, \mathrm{Pr}$, $\mathrm{Nd}$ ) is due to dehydration. The dehydration enthalpies found for $\mathrm{La}, \mathrm{Ce}, \mathrm{Pr}$ and $\mathrm{Nd}$ compounds were: $139.6,57.2,69.1$ and $79.0 \mathrm{~kJ} \mathrm{~mol}^{-1}$, respectively. The broad exotherms observed for all compounds between $350^{\circ} \mathrm{C}$ and $\geq 600^{\circ} \mathrm{C}$, without the appearance of definitive peaks, are attributed to the thermal decomposition of the anhydrous compounds, where the oxidation of the organic matter takes place in consecutive steps except for the cerium compound. The small endothermic peaks at $255^{\circ} \mathrm{C}(\mathrm{Ce})$ and $245^{\circ} \mathrm{C}(\mathrm{Sm})$ are due to monotropic polymorphic transformation, and the small endothermic peaks at $268^{\circ} \mathrm{C}(\mathrm{Ce}), 275^{\circ} \mathrm{C}(\mathrm{La}, \mathrm{Pr}$, $\mathrm{Sm})$ and $282^{\circ} \mathrm{C}(\mathrm{Nd})$ are attributed to the enantiotropic polymorphic transformation. The DSC curves also show that the oxidation of the organic matter are still being observed up to $600^{\circ} \mathrm{C},\left(580^{\circ} \mathrm{C}\right.$ for the samarium compound), while the TG and DTG curves display temperatures that do not exceed $550^{\circ} \mathrm{C}$. This difference is undoubtedly provoked by the crucible with perforated cover used to obtain the DSC curves, while a crucible without perforated cover is used for recording the TG and DTG curves.

\section{Conclusions}

From analytical and thermoanalytical (TG) results a general formula could be established for these compounds in the solid state.

The X-ray powder patterns pointed out that the synthesized compounds have a crystalline structure and only the La and Pr show evidence concerning to the formation of isomorphous compounds.

The infrared spectroscopic data suggest that the $4-\mathrm{MeO}-\mathrm{Bz}$ acts as a bidentate ligand towards the metal ions considered in this work.

The TG-DTA and DSC curves provided previously unreported information about the thermal behaviour and thermal decomposition of these compounds.

\section{Acknowledgements}

The authors thank FAPESP (Proc. 97/126468), $\mathrm{CNPq}$ and CAPES Foundations (Brazil) for financial support and computational facilities of IQUNESP and CENAPAD-UNICAMP.

Recebido em : 07/12/2005

Aceito em : 24/01/2006 
E. C. Rodrigues, A. B. Siqueira, E. Y. Ionashiro, G. Bannach e M. Ionashiro. Síntese, caracterização e comportamento térmico dos 4-metoxibenzoatos de lantânio (III) e lantanídeos leves trivalentes.

Resumo: Compostos M - L foram sintetizados no estado sólido, onde M representa os íons trivalentes $\mathrm{La}, \mathrm{Ce}, \mathrm{Pr}, \mathrm{Nd}$ e Sm, e L é o ânion 4 - metoxibenzoato. Esses compostos foram caracterizados e estudados, utilizando-se as técnicas de difração de raios x pelo método do pó, espectroscopia na região do infravermelho, complexometria, termogravimetria-análise térmica diferencial simultânea (TG-DTA) e DSC. Os resultados permitiram obter informações com respeito à estequiometria, desidratação, transformação polimórfica, ligação metal- ligante, comportamento térmico e decomposição térmica.

Palavras-chave: lantanídeos leves; 4-metoxibenzoato; caracterização e comportamento térmico.

\section{References}

[1] S. J. Yun, S. K. Kang, S. S. Yun, Thermochim. Acta 331(1) (1999) 13.

[2] Z. M. Wang, L. J. Van de Burgt, G. R. Choppin, Inorg. Chim. Acta 167 (1999) 293.

[3] N. Arnaud, J. Georges Analyst, 125 (8) (2000) 1487.

[4] G. R. Choppin, P. A. Bertrand, Y. Hasegawa, N. Rizalla, Inorg. Chem. 21 (10) (1982) 3722.

[5] A. W. H. Lam, W. T. Wang, S. Gao, G. Wen, X. X. Zhang,

Eu. J. Inorg. Chem. (1) (2003) 149.

[6] W. W. Wendlandt. Anal. Chim. Acta. 17(3) (1957) 295.

[7] W. W. Wendlandt. Anal. Chem. 29(5) (1957) 800.

[8] A. K. J. Galwey, J. Chem. Society 1152 (1965) 6188.

[9] S. B. Pirkes, G. N. Makushova, A. V. Lapitskaya, Russian J. Inorg. Chem. 21 (1976) 661.

[10] S. B. Pirkes, A. V. Lapitskaya, G. N. Makushova, Russian J. Inorg. Chem. 21 (1976) 816.

[11] G. N. Makushova, A. V. Lapitskaya, S. O. Goppe, S. B. Pirkes, Russian J. Inorg. Chem. 24 (1979) 1574.

[12] S. B. Pirkes, G. N. Makushova, A. V. Lapitskaya, N. P. Tsilina, Russian J. Inorg. Chem. 28 (1983) 1684.

[13] G. N. Makushova, S. B. Pirkes, Russian J. Inorg. Chem. 29 (1984) 531.

[14] G. N. Makushova, S. B. Pirkes, E. Yu. Levina, Russian J. Inorg. Chem. 30 (1985) 652.

[15] G. N. Makushova, S. B. Pirkes, E. Yu. Levina, Zhurnal Neorganicheskoi Khimii 30 (9) (1985) 2273.

[16] G. N. Makushova, S. B. Pirkes, J. Inorg. Chem. 32 (1987) 489.

[17] W. Lewandowski, J. Molec. Strut. 101 (1-2) (1983) 93.

[18] W. Lewandowski, H. Baranska, J. Raman Spectroscopy 17 (1) (1986) 17.

[19] T. Glowiak, H. Kozlowski, L. Strinna Erre, B. Gulinati, G. Micera, A. Pozzi, S. Brunni, J. Coord. Chem. 25 (1992) 75.

[20] W. Brzyska, S. Karasinski, J. Thermal Anal. 39 (1993) 429.

[21] W. Ferenc, B. Bocian, J. Thermal Anal. Cal. 62 (3) (2000) 831.

[22] B. Bocian, B. Czajka, W. Ferenc, J. Thermal Anal. Cal. 66 (3) (2001) 729.

[23] B. Czajka, B. Bocian, W. Ferenc, J. Thermal Anal. Cal. 67 (3) (2002) 631.

[24] W. Ferenc, B. Bocian, J. Thermal Anal. Cal. 74 (2) (2003) 521.

[25] W. Ferenc, A. Walkow-Dziewulska, J. Thermal Anal. Cal. 71 (2) (2003) 375.
[26] N. S. Fernandes, M. A. S. Carvalho Filho, C. B. Melios, M. Ionashiro, J. Thermal Anal. Cal. 73 (1) (2003) 307.

[27] N. S. Fernandes, M. A. S. Carvalho Filho, R. A. Mendes, C. B. Melios, M. Ionashiro, J. Thermal Anal. Cal. 76 (1) (2004) 193.

[28] W. Ferenc, B. Bocian, A. Walków-Dziewulska, J. Thermal Anal. Cal. 76 (1) (2004) 179.

[29] E. C. Rodrigues, A. B. Siqueira, E. Y. Ionashiro, G. Bannach, M. Ionashiro, J Thermal Anal. Cal. 79 (2005) 323.

[30] H. A. Flaschka, EDTA Titrations; Pergamon Press; Oxford, 1964.

[31] M. Ionashiro, C. A. F. Graner, J. Zuanon Netto, Ecl. Quim. 8 (1983) 29.

[32] T. H. Dunning Jr, P. J. Hay, Modern Theoretical Chemistry, Ed. H. F. Schaefer; New York; 1976, pp. 1-28.

[33] P. J. Hay, W. R. Wadt, J. Chem. Phys. 82 (1) (1985) 270.

[34] W. R. Wadt, P. J. Hay, J. Chem. Phys. 82 (1) (1985) 284.

[35] P. J. Hay, W. R. Wadt, J. Chem. Phys. 82 (1) (1985) 299.

[36] C. C. J. Roothan, Rev. Mod. Phys. 23 (1951) 69.

[37] M. J. Frisch, G. W. Trucks, H. B. Schlegel, G. E. Scuseria, M. A. Robb, J. R. Cheeseman, V. G. Zakrzewski, J. A. Montgomery, Jr., R. E. Stratmann, J. C. Burant, S. Dapprich, J. M. Millam, A. D. Daniels, K. N. Kudin, M. C. Strain, O. Farkas, J. Tomasi, V. Barone, M. Cossi, R. Cammi, B. Mennucci, C. Pomelli, C. Adamo, S. Clifford, J. Ochterski, G. A. Petersson, P. Y. Ayala, Q. Cui, K. Morokuma, N. Rega, P. Salvador, J. J. Dannenberg, D. K. Malick, A. D. Rabuck, K. Raghavachari, J. B. Foresman, J. Cioslowski, J. V. Ortiz, A. G. Baboul, B. B. Stefanov, G. Liu, A. Liashenko, P. Piskorz, I. Komaromi, R. Gomperts, R. L. Martin, D. J. Fox, T. Keith, M. A. Al-Laham, C. Y. Peng, A. Nanayakkara, M. Challacombe, P. M. W. Gill, B. Johnson, W. Chen, M. W. Wong, J. L. Andres, C. Gonzalez, M. Head-Gordon, E. S. Replogle, J. A. Pople, Gaussian 98, Revision A.11.2. Gaussian, Inc., Pittsburgh PA, 2001.

[38] G. Socrates, Infrared Characteristic Group Frequencies, Wiley; New York, 2nd ed. 1994, pp.91 and 236-237.

[39] R. M. Silverstein, F. X. Webster, Spectrometric Identification of Organic Compounds, Wiley, New York, 6th ed., 1998, pp. 92, 93, 96 and 97.

[40] W. Lewandowsky, H. Baranska, J. Raman Spect. 17 (1) (1986) 17.

[41] D. Z. Goodson, S. K. Sarpal, Phlilppe Bopp, M. Wolfsberg, J. Phys. Chem., 86 (1982) 659.

[42] H. B. Schelegel. In new theoretical concepts for understanding organic reaction. J. Berdron Ed., Academic: The Netherlands; 1989, pp 33-53. 